\title{
Magnetostatic Fields in Multilayer Composite Films with a Bimodal Granule Size Distribution
}

\author{
I.G. Shipkova, Yu.I. Veretennikova*, H.A. Kholodov
}

\author{
National Technical University "Kharkiv Polytechnic Institute», 2, Kyrpychova St., 61002 Kharkiv, Ukraine
}

(Received 19 March 2021; revised manuscript received 06 August 2021; published online 20 August 2021)

\begin{abstract}
Numerical calculations of internal fields in multilayer nanostructures composed of magnetic composite layers and nonmagnetic interlayers were carried out. Systems with bimodal granule size distribution were examined. Models of such systems were formed by rearrangement and coalescence of granules inside each layer of a monomodal regular structure while maintaining magnetic particle volume concentration. Magnetic fields at the positions of certain granules were calculated as the vector sum of the dipole fields generated by all the granules in the system. Model parameters corresponded to the characteristics of real multilayer composite nanostructures with a magnetic phase content below the percolation threshold. Thus, for a composite with a granule magnetization of $1250 \mathrm{G}$, the content of the magnetic phase in the layers was chosen equal to 13 vol. \%. Small particles were $3 \mathrm{~nm}$ in size. The calculations were carried out for a different number of particle positions in the system $\left(10^{2}-10^{7}\right)$, and it was found that the results of calculations after exceeding the number of points $\sim 10^{5}$ practically do not change. The intervals between the values of local fields at various layer points were determined depending on the nonmagnetic interlayer thickness (from 2 to $4 \mathrm{~nm}$ ). It was shown that the difference in the values of local dipole fields in a system with the considered bimodal distribution of granules might amount to $\sim 1500$ Oe.
\end{abstract}

Keywords: Composite, Multilayer nanostructure, Magnetic dipole, Internal field, Numerical calculations.

DOI: $10.21272 /$ jnep.13(4).04010

PACS numbers: 75.75. - c, 75.70.Cn

\section{INTRODUCTION}

Nanogranular magnetic systems are considered as promising materials for microwave electronics. It is found that granular structures containing ferromagnetic particles of $3 d$-metals can exhibit a high degree of absorption of microwave radiation [1,2]. Multilayer nanogranular structures are a separate class of granular systems consisting of layers in which ferromagnetic nanoparticles are distributed in a dielectric matrix and interlayers of nonmagnetic dielectric or semiconductor materials. The characteristics of such systems can be controlled by changing not only the concentration of the magnetic phase in the composite layers, but also the thickness of magnetic layers and nonmagnetic interlayers.

As is known, the magnetic and magnetic resonance properties of materials (fields of ferromagnetic resonance, resonance line width) are determined by internal magnetic fields [3]. Therefore, the definition of internal fields can be useful when considering a wide range of problems, both fundamental and applied. Calculation of magnetostatic fields for particle ensembles has been carried out in many papers with the aim of obtaining analytical expressions for regular systems (for example, [4]). However, in real systems there are certain deviations from the ideal models, such as nonperiodic spatial arrangement of particles, different sizes and shapes of granules, as well as the type of their distributions (mono-, bimodal or log-normal) [5-10]. In addition, due to the long-range nature of the dipole interaction the results of calculations can also depend on the size of the simulated system. In this connection, in some cases numerical calculations of the dipole fields can be useful for specific systems with parameters that take into account possible deviations from the ideal correct models. Earlier, in [11], we considered the case of the effect of irregularity in the arrangement of gran. ules in the layer plane on the values of internal fields in multilayer structures with different concentrations of granules in the composite layers. In this paper, we present the results of numerical calculations of internal fields in multilayer nanostructures with a bimodal particle size distribution.

\section{MODEL AND CALCULATION FEATURES}

The basic simplified model of a multilayer structure is a stack of several layers with a regular arrangement of identical granules (Fig. 1). The problem is as follows: find the magnetic field strength at some point $(k)$ located at a distance $d$ vertically from the plane filled with magnetic dipoles $p$ located at the nodes of a square grid with side $a$. The directions of the dipole moments are the same, which is achieved by applying an external magnetic field parallel to the plane of the dipoles.

The magnetic field created by all dipoles at a point at a certain distance from the plane can be written as the vector sum of the fields created by each particle (magnetic dipole) at that point. The distance from the point to the particle should be greater than the particle size.

$$
\vec{H}\left(\vec{r}_{k}\right)=\sum_{i=1}^{N}\left(R_{i k}\right)^{-3}\left[-\vec{p}_{i}+3 \vec{R}_{i k}\left(\vec{p}_{i} \cdot \vec{R}_{i k}\right) \cdot R_{i k}^{-2}\right]
$$

Here $\quad \vec{R}_{i k}=\vec{r}_{k}-\vec{r}_{i}, \quad\left|\vec{R}_{i k}\right|=R_{i k}=\left|\vec{r}_{k}-\vec{r}_{i}\right|, \quad \vec{r}_{i}, \vec{r}_{k}$ are the radius vectors of points under study.

Summation is not performed when $i=k$.

\footnotetext{
*veretennikova.fiz@gmail.com
} 


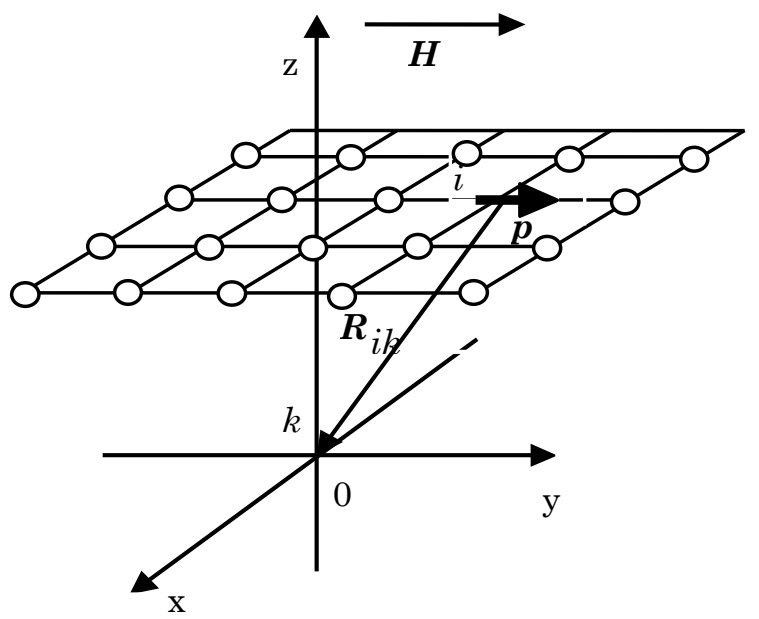

Fig. 1 - Layout of magnetic dipoles in a layer that creates a magnetic field at some point in space

Let us consider the case when the plane is above the particle at height $z$, the origin of coordinates is placed at the point where the field will be calculated. The dipole coordinates $x$ and $y$ are connected to the side of the square grid $a$ with integers $n$ and $m$, that is $x=n a$ and $y=m a$. The expression under the sum sign in this case takes the form:

$$
\vec{H}=\frac{1}{\sqrt{\left(x^{2}+y^{2}+z^{2}\right)^{3}}}\left[-\vec{p}_{i}+\frac{3 \vec{R}_{i k} \cdot(-y \cdot p)}{\left(x^{2}+y^{2}+z^{2}\right)}\right] .
$$

Accordingly, the projection of the dipole field on the direction of the external magnetic field $(Y)$ can be written as follows:

$$
H_{y}=\frac{-p\left(x^{2}+2 y^{2}+z^{2}\right)}{\sqrt{\left(x^{2}+y^{2}+z^{2}\right)^{5}}} .
$$

To calculate the total projection of the fields at a certain point of the plane (for example, at the central point), it is necessary to determine the contributions from the fields created by granules of adjacent layers located above and below the layer in question, as well as granules of the layer itself where this point is located. A special program was compiled for field summation over all points of granule location. As the physical parameters, the characteristics close to those of real multilayer systems were used in computation. We considered the system $\left\{\left[\left(\mathrm{Co}_{40} \mathrm{Fe}_{40} \mathrm{~B}_{20}\right)_{c}\left(\mathrm{SiO}_{2}\right)_{1-c}\right] / \mathrm{SiC}\right\}_{n}[12]$ with a volume concentration of magnetic granules below the percolation threshold $c=13$ vol. \%. The saturation magnetization of granules $I_{S}$ is $1250 \mathrm{G}$, the diameter of individual granules $D$ is $3 \mathrm{~nm}$, the thickness of the nonmagnetic interlayer is 2 and $4 \mathrm{~nm}$. With such characteristics, the system is in a superparamagnetic state [13]. A particle state close to a state with a uniform magnetization distribution is achieved in sufficiently large fields. In practice, this is possible when studying ferromagnetic resonance in the microwave range.

It is common knowledge that for a composite film prepared by simultaneous or sequential evaporation (or sputtering) of metallic and dielectric materials, metal particles located in a dielectric matrix and having a shape close to spherical are formed. The sizes of such particles depend on the concentration and the method of manufacture. Various situations are possible, for instance, when the granules have practically the same size [6] or the granule size distribution has a certain character (log-normal distribution [9, 10], bimodal distribution [6, 7]). A bimodal distribution can be observed at metal concentrations approaching the percolation threshold, when closely spaced finer granules coalesce into larger complexes. In our work, we will consider a model corresponding to this case. We carried out the calculation for a model in which complexes of spherical granules consisting of five particles were formed from small spherical granules.
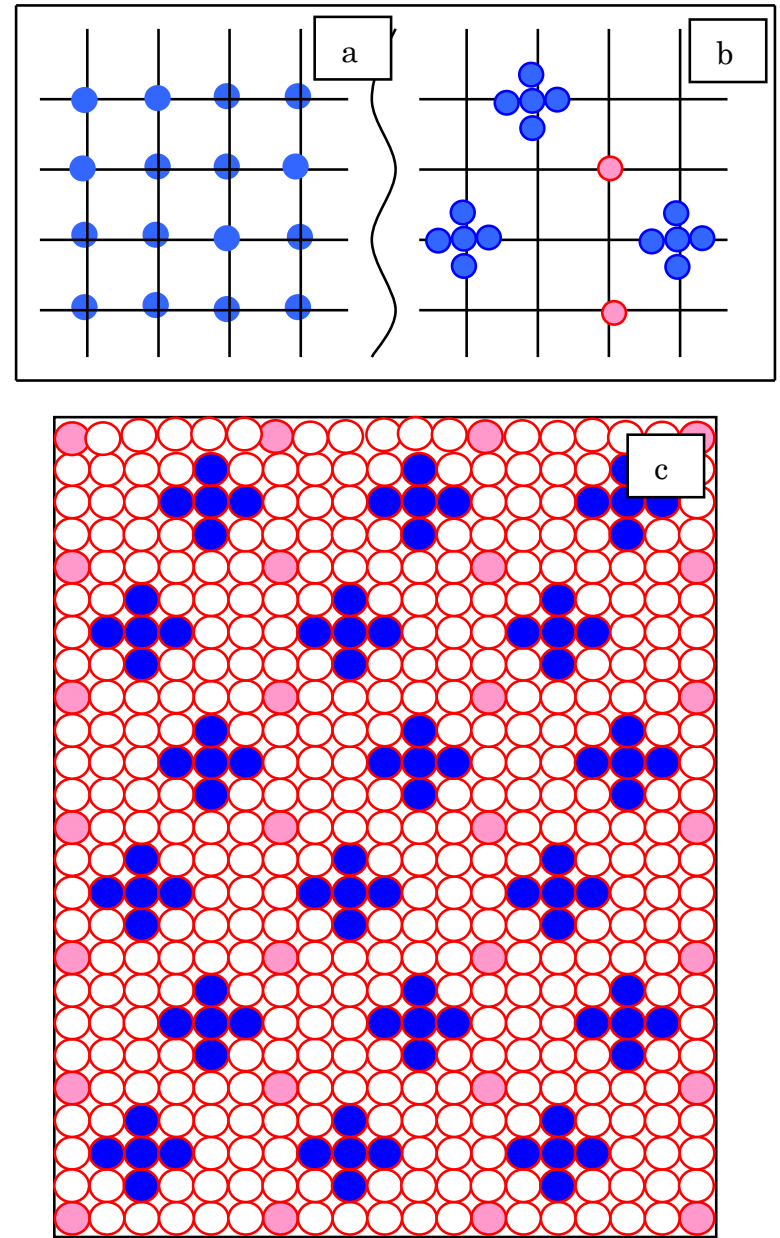

Fig. 2 - Transition from a simple model of individual granules (a) to a model with single granules and complexes of granules $(b, c)$. The volume of the magnetic phase is unchanged

The rearrangement of the granules of the basic system (Fig. 2a) was carried out in such a way that the total volume of all particles (large and small) did not change. At a total concentration of magnetic granules $c=13 \mathrm{vol}$. \% the volume of large granule fraction $c_{1}$ was 9.9 vol. $\%$ and the volume of small granule fraction $c_{2}$ was 3.1 vol. \%. As the central point where we calculated the magnetic field created by all granules of the system, we considered either a small granule or an adjacent complex of granules. The model scheme is shown 
in Fig. 2c. Materials with such a set of parameters should have a magnetization curve shown in Fig. 3. The magnetization curve for separate fractions is shown in this figure too. Both fractions are superparamagnetic, and they are described by the Langevin function [13].
The resulting magnetic moment $I$ in a magnetic field $H$ is the sum of the magnetic moments of two subsystems, namely, large granules and small granules.

Here, $V_{g r 1}, V_{g r 2}$ are the volumes of large and small particles, respectively, $T$ is the temperature equal to $300 \mathrm{~K}$ in the calculation; $k_{B}$ is the Boltzmann constant.

$$
I=c_{1} \cdot I_{S} \cdot\left(\operatorname{cth} \frac{I_{S} \cdot V_{g r 1} \cdot H}{k_{B} \cdot T}-\frac{k_{B} \cdot T}{I_{S} \cdot V_{g r 1} \cdot H}\right)+c_{2} \cdot I_{S} \cdot\left(\operatorname{cth} \frac{I_{S} \cdot V_{g r 2} \cdot H}{k_{B} \cdot T}-\frac{k_{B} \cdot T}{I_{S} \cdot V_{g r 2} \cdot H}\right) .
$$

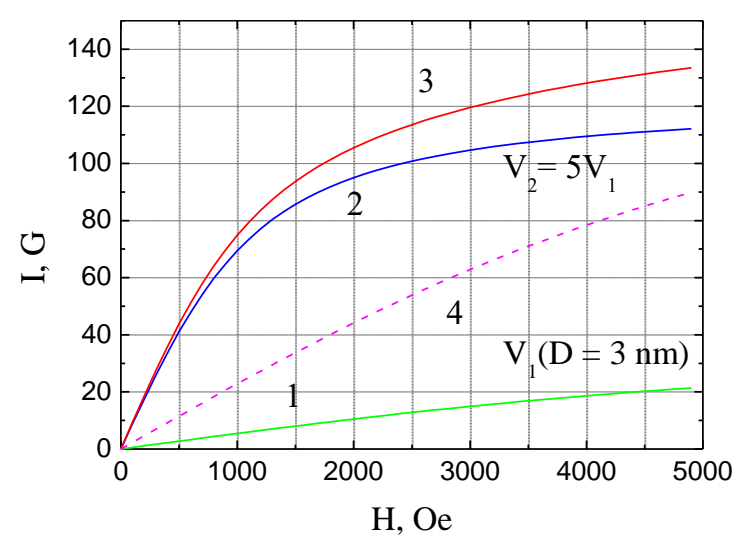

Fig. 3 - The magnetization curve of a granular system consisting of two subsystems that contain superparamagnetic particles with different volumes $V$ (the parameters of the subsystems correspond to the model used to calculate the local dipole fields). 1magnetization curve for a subsystem of particles with a diameter $D=3 \mathrm{~nm}$, the volume concentration of particles of this fraction $c=3.1$ vol. $\% ; 2$ - the magnetization curve for a subsystem of complexes containing five particles, $c=9.9$ vol. $\%$; $3-$ the resulting curve of the entire system (subsystems 1 and 2), $c=13.0$ vol. $\% ; 4-$ magnetization curve for a system consisting of identical particles with $D=3 \mathrm{~nm}, c=13.0$ vol. $\%$

\section{RESULTS AND DISCUSSION}

Since the dipole interaction decreases rather quickly with increasing distance $\left(\sim 1 / r^{3}\right)$, we limited ourselves to a relatively small number of layers, namely five layers above the central plane and below it. In this case, the values of the fields from the distant layers were two orders of magnitude less than from the neighboring ones with respect to the point under consideration. The number of points in one quadrant of each layer was initially $10 \times 13$ (see Fig. 2c). The results of calculating $H_{\text {ysum }}$ after rearrangement at a point located under the central complex of granules depending on the interlayer thickness $d$ are shown in Fig. 4, curve 1 .

In order to assess the influence of the number of dipoles on the calculation results, we changed the dimensions of the plane. Initially, with increasing each side of the plane (by a factor $n$ ) significant changes in the values of $H_{y}$ were observed. As example, in Fig. 4, curve 2 is shown for $n=30$.

Further expansion of the plane did not cause noticeable changes in $H_{y s u m}$ (curve 3 in Fig. 4 for $n=300$ ). The same tendency was observed if the central point was located in the place of a small granule. In what follows, we will discuss the results for these last cases, which correspond to $4 \times 10^{7}$ positions on the plane.

It should be noted that if we place the granule at the point where we calculate the sum of the dipole fields

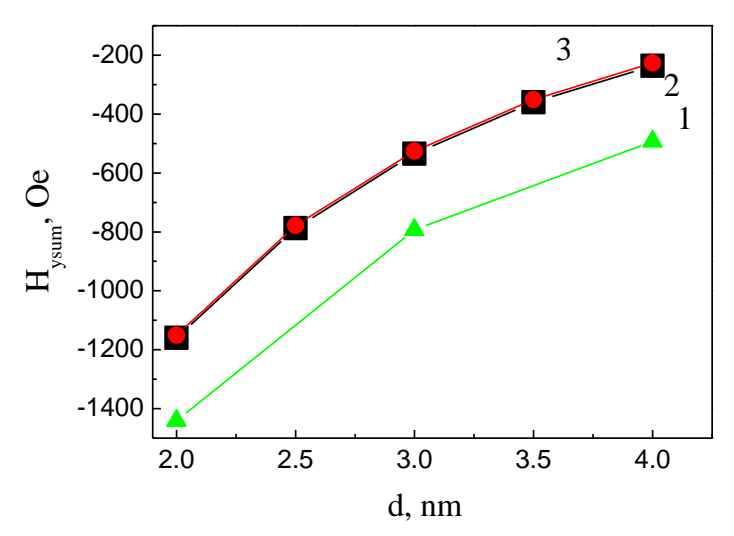

Fig. 4 - The dipole fields induced by all particles in the location of the central granule complex depending on the interlayer thickness for various array sizes: curve 1 - the number of points in one quadrant are $10 \times 13$; curve $2-300 \times 390$; curve $3-3000 \times 3900$

$H_{y s u m}$, then the local field inside the granule will consist of the external field, demagnetizing field of the particle itself and the mentioned sum of dipole fields. The $H_{y s u m}$ value is an additive that can be controlled without changing the concentration of the magnetic phase, but changing the nature of the particle size distribution. The example of a bimodal distribution model we have considered shows how strong the influence of the scatter of particle sizes can be.

Fig. 5 and Table 1 demonstrate the results of calculations of the component $H_{\text {ssum }}$ created by a system of dipoles in two adjacent positions. As we can see, the dipole fields $H_{\text {ysum }}$ at the points located under individual granules and under the complexes of granules differ in magnitude and direction of the field. This difference increases up to $\sim 1500$ Oe with reducing thickness of a nonmagnetic interlayer down to $2 \mathrm{~nm}$.

Quantitatively, the additive $H_{y s u m}$ can affect the magnetic and especially the magnetic resonance characteristics of multilayer structures.

As is known, the equation of magnetization motion, which makes it possible to calculate the frequency of ferromagnetic resonance $\frac{\partial \vec{M}}{\partial t}=-\gamma\left[\vec{M}, \vec{H}_{e f}\right]$ includes the socalled effective field $H_{e f}$, which is the sum of fields of different origins: external field, crystallographic anisotropy field, shape anisotropy field, etc. [14]. If the additive to the local field associated with the granule dipole fields is comparable to the fields of other origin and changes from point to point, a noticeable broadening of the resonance line of the entire sample should be expected. In our case, according to calculations, the effect of the dipole sum and its changes should be significant for the model of a structure with an interlayer thickness of $2 \mathrm{~nm}$, 
Table 1 - Calculated values of dipole fields in two closely spaced points of a layer of a multilayer composite structure with different thickness $d$ of a nonmagnetic interlayer $\left(H_{y 1}\right.$ is the field generated by the granules of adjacent planes, $H_{y 2}$ is the field generated by the granules of the plane where the point is located, $H_{\text {ysum }}$ is the resultant field component along the $Y$ axis)

\begin{tabular}{|l|c|c|c|c|c|c|}
\hline \multirow{2}{*}{\multicolumn{1}{c|}{ Point position }} & \multicolumn{3}{c|}{$d=2 \mathrm{~nm}$} & \multicolumn{3}{c|}{$d=4 \mathrm{~nm}$} \\
\cline { 2 - 7 } & $H_{y 1}, \mathrm{Oe}$ & $H_{y 2}, \mathrm{Oe}$ & $H_{y s u m}, \mathrm{Oe}$ & $H_{y 1}, \mathrm{Oe}$ & $H_{y 2}, \mathrm{Oe}$ & $H_{y s u m}, \mathrm{Oe}$ \\
\hline Under individual granule & 28 & 309 & 337 & 61 & 309 & 370 \\
\hline Under complex of granules & -1305 & 154 & -1151 & -380 & 154 & -226 \\
\hline Under granule in monomodal system & -82 & 369 & 287 & -10 & 369 & 359 \\
\hline
\end{tabular}

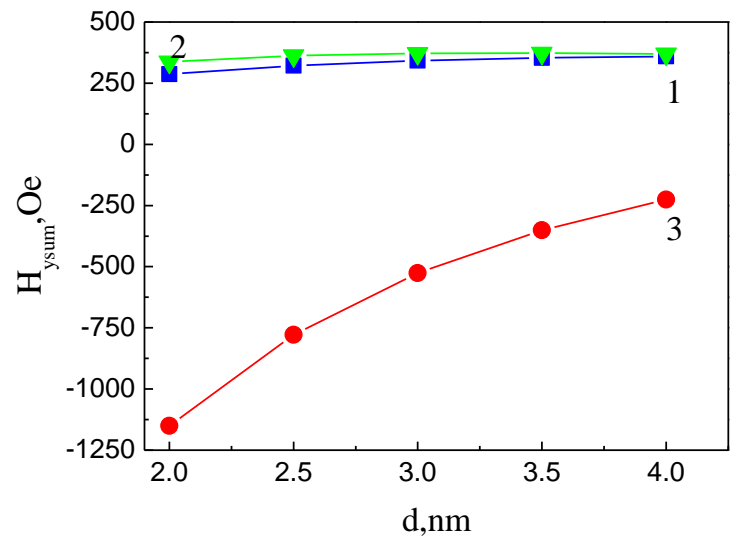

Fig. 5 - Dipole fields induced by all particles in the location of the central granule of the monomodal system (curve 1), individual central granule of the bimodal system (curve 2), and the central complex of granules (curve 3) of the bimodal system as function of the interlayer thickness

since the demagnetizing fields of an individual granule and a complex of granules have the same order of magnitude as the dipole sum (thousands of Oersteds). For an interlayer thickness of $4 \mathrm{~nm}$, the contribution of the dipole sum will be noticeably smaller (see Table 1).

\section{REFERENCES}

1. J.V.I. Timonen, R.H.A. Ras, O. Ikkala, et al., Magnetic Nanocomposites at Microwave Frequencies: In book Trends in Nanophysics: Theory, Experiment, Technology, (Eds. by V. Barsan, A. Aldea) (Berlin: Springer-Verlag: 2010).

2. S. Bibikov, M. Procofev, Composite Materials for Some Radiophysics Applications: In book Metal, Ceramic and Polymeric Composites for Various Uses (Edited by John Cuppoletti: 2001).

3. D.S. Schmool, R. Rocha, J.B. Sousa, et al., J. Appl. Phys. 101, 103907 (2007).

4. V.A. Ignatchenko, I.S. Edelman, D.A. Petrov, Phys. Rev. B 81, 054419 (2010).

5. D.S. Il'yushchenkov, V.I. Kozub, I.N. Yassiyevich, Phys. Solid State 49 No 10, 1853 (2007).

6. D. Kumar, S. Chaudhary, D.K. Pandya J. Appl. Phys. 114, 023908 (2013).

7. B. Zhou, B.S.D.C.S. Varaprasad, E. Zhang, D.E. Laughlin, J-G. Zhu, IEEE Trans. Magn. 54, No 11, 1 (2018).

\section{CONCLUSIONS}

The results of numerical calculations of dipole fields in multilayer nanostructures with a bimodal particle size distribution are presented. We have considered a model of a multilayer structure consisting of layers, which are ensembles of regularly spaced magnetic nanogranules of two sizes, and nonmagnetic interlayers. The model parameters corresponded to the characteristics of real multilayer composite nano-structures with a magnetic phase content below the percolation threshold. The interlayer thickness varied from 2 to $4 \mathrm{~nm}$. In the course of calculations, the dimensions of the array of layer points were established, after exceeding which the results of field calculations practically do not change $\left(4 \cdot 10^{5}\right.$ positions on the plane).

The fields at the central point of the system are compared for the cases of mono- and bimodal particle size distribution. It was found that with a bimodal distribution, there is a large difference in the values of local dipole fields at the points located under the individual granules and under their complexes (up to $1500 \mathrm{Oe}$ ). The difference lies not only in the magnitude, but also in the direction of the field. This difference increases with decreasing thickness of the nonmagnetic layer. The data obtained can be useful in interpreting the results of measurements of magnetic and resonance properties of multilayer nanostructures, as well as when developing materials for microwave electronics.

8. A. Yurasov, E. Gan'shina, A. Sokolov, et al., EPJ Web Conf. 185, 02009 (2018)

9. G. Ennas. A. Falqur, G. Piccaluga, S. Solinas, et al., Z. Naturforsch. 55a, 581 (2000).

10. K. Yakushiji, S. Mitani, K. Takanashi, J.-G. Ha, H. Fujimori, J. Magn. Magn. Mater. 212, 75 (2000).

11. Iu.I. Veretennikova, I.G. Shipkova, E.A. Zhelunitsina IEEE 7th International Conference Nanomaterials: Application \& Properties (NAP-2017), 02MFPM07 (2017).

12. I. Shipkova, Ju. Chekrygina, A. Devizenko, et al., Solid State Phenomena 233-234, 633 (2015).

13. D.-X. Chen, A. Sanchez, E. Taboada, et al., J. Appl. Phys. 105, 083924 (2009).

14. J.E. Miltat, M.J. Donahue, Numerical Micromagnetics: Finite Difference Methods: In book Handbook of Magnetism and Advanced Magnetic Materials, Volume Micromagnetism (Eds. by H. Kronmuller, S Parkin) (John Wiley \& Sons, Ltd.: 2007). 


\section{Магнітостатичні поля у багатошарових композитних плівках з бімодальним розподілом гранул за розміром}

\section{І.Г. Шипкова, Ю.І. Веретеннікова, Г.А. Холодов}

Національний технічний університет "Харківський політехнічний інститут», вул. Кирпичова, 2, 61002 Харків, Украӥна

Виконано чисельні розрахунки внутрішніх полів в багатошарових наноструктурах, що містять ма гнітні композитні шари та немагнітні прошарки. Розглянуто системи з бімодальним розподілом гранул за розміром. Моделі таких систем було сформовано шляхом перестроювання та коалесценції гранул усередині кожного шару мономодальної регулярної структури при збереженні об’емної концентрації магнітних частинок. Магнітні поля в позиціях певних гранул були розраховані як векторна су ма дипольних полів, створюваних гранулами всіеї системи. Параметри моделі відповідали характеристикам реальних мультишарових композитних наноструктур із вмістом магнітної фази нижче порогу перколяції. Так, для композиту з намагніченістю гранул 1250 Гс, вміст магнітної фази в шарах було вибрано рівним 13 об. \%. Розміри малих частинок становили 3 нм. Розрахунки було проведено для різної кількості позицій частинок в системі $\left(10^{2}-10^{7}\right)$ та встановлено, що результати розрахунків після перевищення числа точок $\sim 10^{5}$ практично не змінюються. Було визначено інтервали значень локальних полів у різних точках шару в залежності від товщини магнітного прошарку (від 2 до 4 нм). Було показано, що різниця у величинах локальних дипольних полів в системі з розглянутим бімодальном розподілом гранул може досягати $1500 \mathrm{E}$

Ключові слова: Композит, Багатошарова наноструктура, Магнітний диполь, Внутрішне поле, Чисельні розрахунки. 